\title{
Assessing Flood Vulnerability of Opak Watershed According to the Review of BNPB Regulation
}

\author{
Nursetiawan $^{1 *}$, Nurrahmat Sena Aji Pamungkas ${ }^{1}$ \\ ${ }^{1}$ Department of Civil Engineering, Universitas Muhammadiyah Yogyakarta, Indonesia \\ *Corresponding author.Email: nuursetiawan@umy.ac.id
}

\begin{abstract}
Special Region of Yogyakarta is a province that is quite densely populated due to many migrants and domestic and foreign tourists visiting and settling in the province. This will have an impact on increasing land needs and meeting needs that can have an impact on declining environmental quality, one of which is the flood disaster. Flood disaster is a serious problem that occurs in the Special Region of Yogyakarta because almost every year floods always occur when the rainy season arrives. This study discusses the analysis of the level of vulnerability of flood disasters in the Opak watershed area with the method used is the scoring and weighting method based on the Regulation of the Head of BNPB Number 2 of 2012 concerning General Guidelines for Disaster Risk Assessment. To determine the level of vulnerability to flooding, only two variables are used, namely physical vulnerability and environmental vulnerability. Of the two vulnerabilities has a total of 6 parameters which include land use, topographic height, distance from the river, slope, Normalized Different Vegetation Index (NDVI), and Topographic Wetness Index (TWI). Based on the results of the analysis that has been done, it can be concluded that the level of vulnerability of flood disasters in the Opak watershed is included in the medium class.
\end{abstract}

Keywords-Flood Vulnerability, TWI, NDVI

\section{INTRODUCTION}

One of the disasters that caused huge losses and threatened several areas of the Special Region of Yogyakarta (DIY) was flooding. A flood disaster is an event or a series of events that can result in a threat and disrupt people's lives caused by natural, non-natural and human-made factors, resulting in many victims, environmental damage, loss of life and property, and psychological impacts [1]. Disasters caused by natural factors include landslides, floods, volcanic eruptions, tsunamis and earthquakes. Meanwhile, disasters caused by non-natural factors include disease outbreaks, transportation accidents and others.

Yogyakarta Special Region (DIY) is a province located on the southern side of Java Island which is directly adjacent to Central Java Province in the north and the Indian Ocean in the south. Yogyakarta Special Region (DIY) has an area of $3,185.8 \mathrm{~km}^{2}$ and is a city that is quite densely populated because many people are immigrants and domestic tourists as well as foreign tourists who visit and settle in the province. Administratively, Yogyakarta is divided into four districts, namely Kulon Progo, Gunungkidul, Sleman and Bantul districts and one municipality (Yogyakarta City). Geographically, Yogyakarta has Mount Merapi, which towers over the border between Central Java and Yogyakarta. With the existence of Mount Merapi, there is a river flow from the upstream that flows from the peak and empties into the South Sea. The rivers that divide the DIY mainland include the Bedok, Gajah Wong, Code and Opak rivers. In this study, it is limited to discussing only one river, namely the Opak River. The Opak River stretches from the slopes of Merapi to its mouth in the South Sea or Indian Ocean.

As the population of an area increases, activities related to rivers such as garbage disposal and household waste disposal also increase. As a result of this, if rain occurs above the peak of Merapi and its surroundings, then the rainwater flows between the rivers which results in flooding overflowing and inundating residential areas. Seeing the magnitude of the impact caused by the flood disaster, an analysis of the level of flood disaster vulnerability can be carried out to reduce the loss of property and casualties by providing knowledge and counseling to the surrounding community in order to carry out prevention related to flood disasters.

\section{ASSESMENT OF THE FLOOD VULNERABILITY OF OPAK RIVER}

\subsection{Vulnerability}

According to the definition of Perka BNPB No. 2 Tahun (2012), vulnerability is a condition of a community or society that leads to or causes inability to face the threat of disaster. Vulnerability can be grouped into four categories, namely physical vulnerability, social vulnerability, economic vulnerability and environmental vulnerability. However, in this study only two vulnerabilities were used, namely physical and environmental vulnerabilities due to limited situations and conditions. 


\subsection{Normalized Different Vegetation Index (NDVI)}

The Normalized Difference Vegetation Index (NDVI) is one of the image calculation methods used to determine the level of greenness which is very good as the beginning of the division of vegetation areas. NDVI can show parameters related to vegetation, including green leaf biomass, and green foliage area which is the value for vegetation distribution [2].

The vegetation index is a mathematical combination of the red band and the Near Infra-Red (NIR) band, which has long been used to separate green vegetation conditions from other surfaces. Basically, NDVI measures the slope between the original value of the red band and the infrared band in space with the red and infrared values present in each image pixel. NDVI values can be calculated using equation 1 .

$$
\mathrm{NDVI}=\frac{\text { Band } 5 \text {-Band } 4}{\text { Band } 5+\text { Band } 4}
$$

Information:

Band $4=$ Band Red

Band $5=$ Near Infra-Red (NIR) Band

NDVI values range from -1 to 1 with a classification of 1-0 including non-vegetation groups and $0-1$ including vegetation groups [3] [4].

\subsection{Topography Wetness Index (TWI)}

Topography Wetness Index is an index of physical effects based on local topography on the direction of runoff and accumulation flow which was first developed by Beven and Kirkby in 1979. TWI is calculated by evaluating flow direction, flow accumulation, and various geometric functions derived using GIS software [5].

The TWI value illustrates the level of land wetness which is assumed to be associated with vulnerability to flood disasters, especially inundation floods. This TWI assessment is implemented with the Digital Elevation Model (DEM) which can be calculated using Equation 2.

$$
W=\ln \frac{\alpha}{\tan \beta}
$$

The value of $\mathrm{W}$ is the wetness index where $\alpha$ is the accumulation of the upper slope that drains water at a point on each contour, while $\beta$ is the angle of the slope at that point. Thus, the TWI value that approaches 1 is on a flat / plain slope, on the other hand, the TWI value approaches 0 on a steep / hilly slope. Areas with high TWI values tend to be more prone to experiencing inundation flooding [6].

\section{RESEARCH METHODS}

\subsection{Research Sites}

The location of the research was conducted in the Special Region of Yogyakarta Province, precisely in the area of the Opak River Basin, which originates at Mount Merapi, Sleman Regency and empties into Samas Beach, Bantul Regency. The
Opak watershed covers 31 sub-districts and consists of 124 villages with an area of approximately $760 \mathrm{~km}^{2}$ of the Opak watershed. The location of the Opak watershed is shown in Fig. 1.

\subsection{Software}

In this research, software in the form of ArcMap is used to process the spatial data of each flood vulnerability parameter that will be used.

\subsection{Scoring / Weighting Methods}

The scoring method is a method of giving a score or value to the class of each parameter to determine its level of ability. This assessment is based on predetermined criteria. Scoring makes calculations easier, so each alternative question for respondents is given a score like the following, a score (1) for the low class, a score (2) for the medium class, and a score (3) for the high class [7].

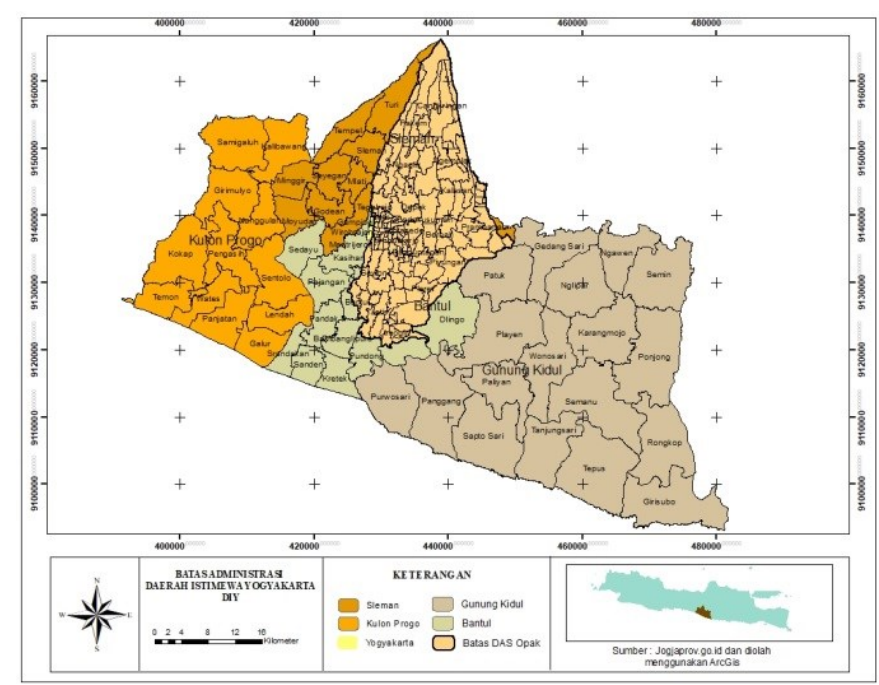

Fig. 1. The Opak watershed

\subsection{Flood Vulnerability level data processing}

There are four vulnerabilities that affect the level of vulnerability of an area to flooding. However, in this study only two vulnerabilities were used, namely physical and environmental vulnerabilities. Each of these vulnerabilities has its own parameters.

\subsubsection{Physical Vulnerability}

The parameters used for physical vulnerability are land use and topographic height. The conversion of physical vulnerability parameters and their equations can be seen in Table I. 
Table I. Conversion of Physical Vulnerability Parameters and Their Equations

\begin{tabular}{lllll}
\hline Parameter & Class & Value & Classification & Weight \\
\hline \multirow{4}{*}{ Land use } & Low & 1 & Forest & \\
& Moderate & 2 & Agriculture \& & $60 \%$ \\
& High & 3 & Plantation & \\
\hline \multirow{2}{*}{ Height of } & Low & 1 & $>200$ masl & \\
Topography & Moderate & 2 & $50-200$ masl & $40 \%$ \\
& High & 3 & $<50$ masl & \\
\hline
\end{tabular}

Physical Susceptibility:

$=0.6 \times$ Land Use Score $)+(0.4 \times$ Topographic Altitude Score)

\subsubsection{Environmental Vulnerability}

The parameters used for environmental vulnerability include distance from the river, slope, Normalized Different Vegetation Index (NDVI) and Topographic Wetness Index (TWI). The conversion of environmental vulnerability parameters and their equations can be seen in Table II.

Table II. Conversion of Environmental Vulnerability Parameters and Their Equations

\begin{tabular}{|c|c|c|c|c|}
\hline Parameter & Class & Value & Classification & Weight \\
\hline \multirow{3}{*}{$\begin{array}{c}\text { Distance } \\
\text { From River }\end{array}$} & Low & 1 & $>100 \mathrm{~m}$ & \\
\hline & Moderate & 2 & $50-100 \mathrm{~m}$ & $20 \%$ \\
\hline & High & 3 & $<50 \mathrm{~m}$ & \\
\hline \multirow{3}{*}{ Slope } & Low & 1 & $0-8 \%$ & \\
\hline & Moderate & 2 & $8-45 \%$ & $30 \%$ \\
\hline & High & 3 & $>45 \%$ & \\
\hline \multirow{3}{*}{ NDVI } & Well & 1 & $0,42-0,92$ & \\
\hline & Normal & 2 & $0.12-0.42$ & $25 \%$ \\
\hline & $\mathrm{Bad}$ & 3 & $(-0.1)-0.12$ & \\
\hline \multirow{3}{*}{ TWI } & Low & 1 & $(-21)-(-17)$ & \\
\hline & Moderate & 2 & $(-17)-(-15)$ & $25 \%$ \\
\hline & High & 3 & $(-15)-(-3)$ & \\
\hline
\end{tabular}

Environmental Vulnerability:

$(0.2 \times$ Distance from River Score $)+(0.3 \times$ Slope Slope Score $)$ $+(0.25 \times$ NDVI Score $)+(0.25 \times$ TWI Score $)$

The following is a reference table for the Flood Vulnerability parameter that refers to the parameters set by the Regulation of the Head of BNPB Number 2 of 2012.
Table III. Vulnerability Parameter Reference

\begin{tabular}{|c|c|c|c|}
\hline No & Parameter & $\begin{array}{l}\text { Perka } \\
\text { BNPB }\end{array}$ & $\begin{array}{c}\text { Non Perka } \\
\text { BNPB }\end{array}$ \\
\hline \multirow[t]{6}{*}{1} & Physical Susceptibility: & & \\
\hline & Building Density & $\sqrt{ }$ & $\sqrt{ }$ \\
\hline & Infrastructure Vulnerability & $\sqrt{ }$ & $\sqrt{ }$ \\
\hline & Drainage conditions & - & $\sqrt{ }$ \\
\hline & Road network & - & $\sqrt{ }$ \\
\hline & Distance from river & - & $\sqrt{ }$ \\
\hline \multirow[t]{5}{*}{2} & Social Vulnerability: & & \\
\hline & Population density & $\sqrt{ }$ & $\sqrt{ }$ \\
\hline & Social sensitivity & $\sqrt{ }$ & $\sqrt{ }$ \\
\hline & Poverty ratio & - & $\sqrt{ }$ \\
\hline & Age group ratio & - & $\sqrt{ }$ \\
\hline \multirow[t]{4}{*}{3} & Economic Vulnerability: & & \\
\hline & GRDP per sector & $\sqrt{ }$ & - \\
\hline & Productive land & $\sqrt{ }$ & $\sqrt{ }$ \\
\hline & Education & - & $\sqrt{ }$ \\
\hline \multirow[t]{6}{*}{4} & $\begin{array}{l}\text { Environmental } \\
\text { Vulnerability: }\end{array}$ & & \\
\hline & Land Use & $\sqrt{ }$ & $\sqrt{ }$ \\
\hline & Slope & $\sqrt{ }$ & $\sqrt{ }$ \\
\hline & Topography & - & $\sqrt{ }$ \\
\hline & $\begin{array}{l}\text { Normalized Difference } \\
\text { Vegetation Index (NDVI) }\end{array}$ & - & $\sqrt{ }$ \\
\hline & $\begin{array}{l}\text { Topographic Wetness Index } \\
\text { (TWI) }\end{array}$ & - & $\sqrt{ }$ \\
\hline
\end{tabular}

\section{RESULTS AND DISCUSSION}

\subsection{Flood Vulnerability Level Analysis}

\subsubsection{Physical Vulnerability}

\subsubsection{Land Use}

The land use analysis results showed that the highest percentage of land use was in the classification of settlements or built-up land with a 3 value and included in the high class. In contrast, the lowest percentage of land use was in forest classification with a value of 1 and was included in the low class.

\subsubsection{Altitude Topography}

The topographic height analysis results revealed that Hargo Binangun Village was the area with the highest topographical location, with an altitude of 1000-1200 m, with a value of 1 , and was included in the low class. Conversely, the areas with the lowest topography were in the villages of 
Timbulharjo, Pendowoharjo, Patalan, Canden, Sumberagung, and Sriharjo, with a score of 3 and included in the high class. The Map of the physical vulnerability analysis results of the Opak watershed is shown in Fig. 2.

Physical Susceptibility:

$=(0.6 \times$ Land Use Score $)+(0.4 \times$

Topographic Altitude Score)

$=(0.6 \times 190.8)+(0.4 \times 96)$

$=152.88$

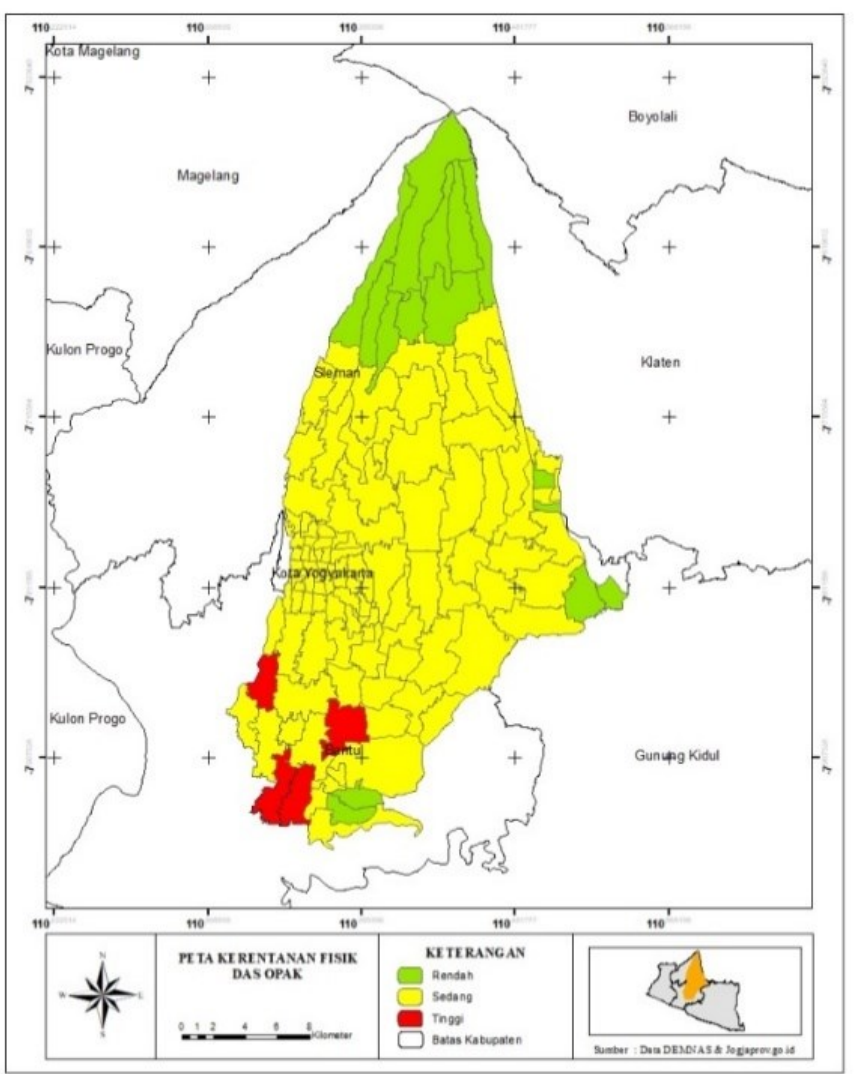

Fig. 2. Map of the physical vulnerability analysis results

\subsubsection{Environmental Vulnerability}

\subsubsection{Distance from the River}

The analysis results found that the villages with the closest distance to the river were Umbulharjo, Bimomartani, Donoharjo, and Prawirodirjan, with a distance of $<50 \mathrm{~m}$, the value of 3 , and belonged to the high class. Meanwhile, the farthest distance areas were Mantrijeron and Panembahan, with a distance of $>500 \mathrm{~m}$, with a value of 1 and included in the low class.

\subsubsection{Slope}

The slope analysis results unveiled that the villages of Hargo Binangun, Wukir Harjo, and Srimulyo had the highest slope, with a percentage of $50 \%$ and a value of 1 , thereby including in the steep class. On the other hand, the lowest slope areas were in Timbulharjo, Bangunharjo, Panggungharjo, Wonokromo, Patalan, Canden,
Sumberagung, and Sriharjo with a percentage of 5\%, belonging to the flat class.

\subsubsection{Normalized Different Vegetasi Index (NDVI)}

The NDVI analysis results discovered that the villages of Hargo Binangun, Purwo Binangun, Kepuh Harjo, Glagah Harjo, Umbulharjo and Sumber Harjo had the highest value of 0.35-0.54 and a value of 1 , thus involving in the good class. Conversely, the lowest score region was dominated by Yogyakarta City, with a score of (-1)-0.28 and a value of 3, hence including in the bad class.

\subsubsection{Topographic Wetness Index (TWI)}

The TWI analysis disclosed that on average, low-class villages with a TWI value of $(-21)-(-17)$ and a value of 1 , comprised Hargo Binangun, Purwo Binangun, Harjo Binangun and others. Meanwhile, Widodomartani, Bimo Martani, Donoharjo, and others belonged to the medium class, with a TWI score of $(-17)-(-15)$ and a value of 3 . The Map of the environmental vulnerability analysis results of the Opak watershed is shown in Fig. 3.

Environmental Vulnerability:

$=(0.2 \times$ Distance from River Score $)+(0.3 \times$ Slope Slope Score $)+(0.25 \times$ NDVI Score $)+(0.25 \times$ TWI Score $)=(0.2 \times 36)+(0.3 \times 45.9)+(0.25 \times 73.5)+(0.25$ $\times 66.54)=55.98$

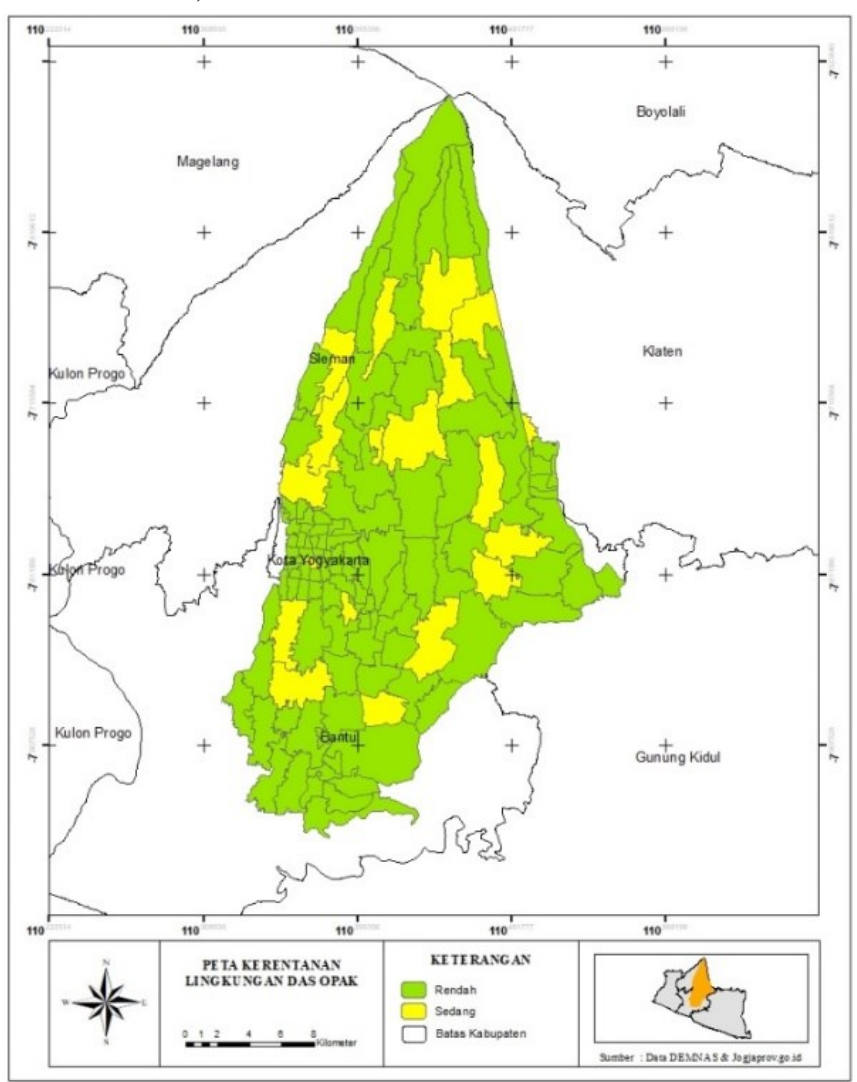

Fig. 3. Map of the environmental vulnerability analysis results 


\subsection{Accumulated Flood Vulnerability Scoring}

This study employed two parameters to analyze the flood vulnerability level, namely, physical and environmental vulnerabilities. The data on vulnerability parameters obtained were analyzed, and the results were classified into three classes of low, medium, and high. Table IV presents the flood vulnerability scoring in this study, while the analysis results of the flood vulnerability scoring are described in Table V.

Table IV. Scoring of Flood Vulnerability Levels

\begin{tabular}{cc}
\hline Class & Score \\
\hline Low & $124-206.67$ \\
Moderate & $206.67-289.34$ \\
High & $289.34-372$ \\
\hline
\end{tabular}

Table V. Analysis Results of the Flood Vulnerability Scoring

\begin{tabular}{ccc}
\hline Parameter & Score & Class \\
\hline Physical Vulnerability & 286.8 & Moderate \\
Environmental Vulnerability & 221.85 & Moderate \\
\hline
\end{tabular}

Total Vulnerability:

$=(0.5 \times$ Physical vulnerability score $)+(0.5 \times$ Environmental vulnerability score)

$=(0.5 \times 286.8)+(0.5 \times 221.85)$

$=(143.4)+(110.93)=254.33($ moderate $)$

In short, the flood vulnerability level in the Opak watershed belongs to the medium class, with a total vulnerability score of 254.33, obtained from the sum of physical and environmental vulnerabilities. The Vulnerability map per village of the Opak watershed is shown in Fig. 4.

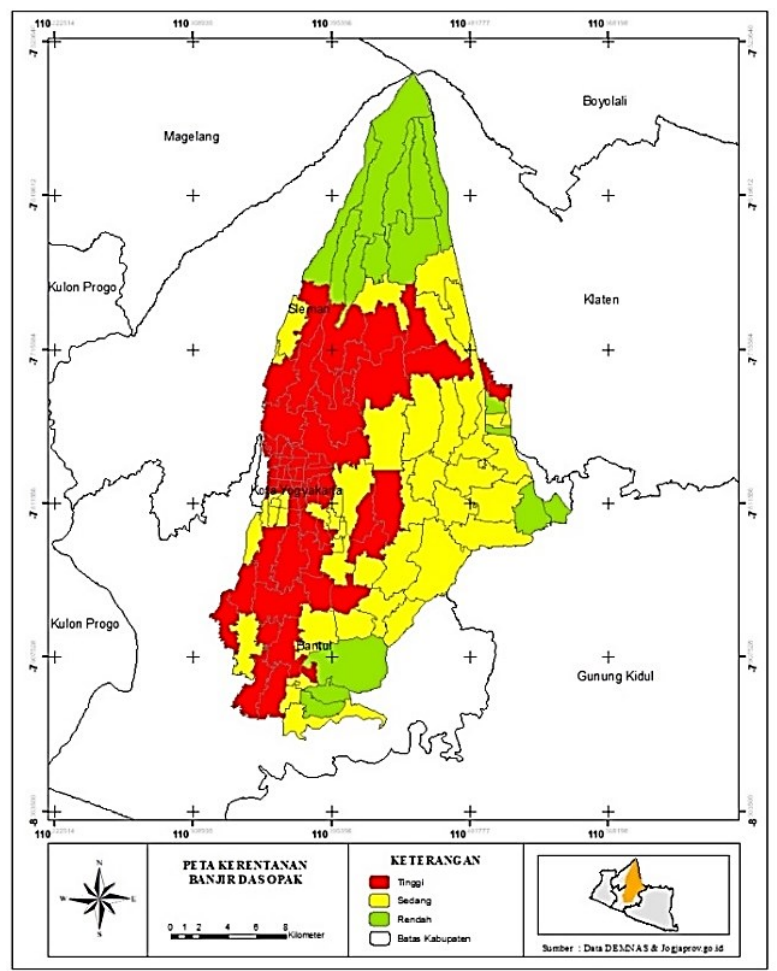

Fig. 4. Vulnerability map per village

\section{CONCLUSIONS}

Not all parameters analyzed by other researchers or experts included in the Head of BNPB Regulation Number 2 of 2012. Only two parameters in each vulnerability contained in Perka BNPB Number 2 of 2012, namely density buildings, infrastructure vulnerability, population density, social sensitivity, GRDP per sector, productive land, land use, and slope. The flood vulnerability level in the Opak watershed can be seen from two vulnerabilities, physical and environmental, belonging to the medium class level.In terms of flood vulnerability level, 16 villages are in a low class, with a total score between 2.5-3.3. Forty-five villages belong to the medium class, with a total score between 3.5-4.3, and 63 villages are in the high class, with a total score between 4.3 4.8 .

\section{REFERENCES}

[1] BNPB, "Peraturan Kepala BNPB Nomor 02 Tahun 2012 Tentang Pedoman Umum Pengkajian Risiko Bencana," BNPB, Jakarta, 2012.

[2] D. R. Putri, A. Sukmono and B. Sudarsono, "Analisis Kombinasi Citra Sentinel-1a Dan Citra Sentinel-2a Untuk Klasifikasi Tutupan Lahan (Studi Kasus: Kabupaten Demak, Jawa Tengah)," Jurnal Geodesi, pp. 85-96, 2018.

[3] I. Philiani, L. Saputra, L. Harvianto and Muzaki, "Pemetaan Vegetasi Hutan Mangrove Menggunakan Metode Normalized Difference Vegetation Index (NDVI) Di Desa Arakan, Minahasa Selatan, Sulawesi Utara.," Journal of Science and Technology, vol. 1, no. 2, p. 211-222, 2016.

[4] E. Birsrat and B. Berhanu, "Identification of Surface Water Storing Sites Using Topographic Wetness Index (TWI) and Normalized Difference Vegetation Index (NDVI)," Journal of Natural Resources and Development, vol. 8, pp. 91-100, 2018.

[5] C. Ballerina, "Topographic Wetness Index Urban Flooding Awareness Act Action Support. Will \& DuPage Counties," Illinois State Water Survey, Illinois, 2017.

[6] F. Nucifera and S. T. Putro, "Deteksi Kerawanan Banjir Genangan Menggunakan Topographic Wetness Index (TWI)," Media Komunikasi Geografi, vol. 2, no. 107116, p. 18, 2018.

[7] J. Risanty, D. Arisanty and E. Alviawati, "Kerentanan Banjir Di Kecamatan Martapura Barat Kabupaten Banjar," JPG (Jurnal Pendidikan Geografi), vol. 5, p. 2, 2016. 